\title{
Vitamin D i koža
}

\section{Vitamin D and the skin}

\author{
Dora Gašparini ${ }^{*}$, Marija Kaštelan ${ }^{1,2}$
}

${ }^{1}$ Sveučilište u Rijeci, Medicinski fakultet, Rijeka, Hrvatska

${ }^{2}$ Katedra za dermatovenerologiju, Klinički bolnički centar Rijeka, Rijeka, Hrvatska

\section{*Dopisni autor:}

Dora Gašparini, dr. med.

Sveučilište u Rijeci, Medicinski fakultet

Braće Branchetta 20, 51000 Rijeka, Hrvatska

E-mail: gasparini.dora@gmail.com
Sažetak. Povezanost vitamina D i kože započinje sintezom vitamina D u koži, a neprestano se istražuju i uočavaju novi mehanizmi kojima najistraživaniji vitamin utječe na najveći organ ljudskoga tijela. Cilj je ovoga rada dati pregled dosadašnjih spoznaja o interakciji vitamina D i kože te utjecaju razina vitamina $D$ na kožne bolesti. Po nekim istraživanjima suboptimalne razine vitamina $D$ nalaze se u čak 30 - $90 \%$ stanovništva, a procjenjuje se da postoji manjak vitamina D u oko jedne milijarde ljudi na cijelome svijetu. U 25,6 - $68 \%$ pacijenata sa psorijazom postoji nedostatak vitamina $D$, a manjak vitamina $D$ nazočan je u čak $97 \%$ pacijenata. Nadalje, niz opservacijskih studija i metaanaliza dokazalo je da su serumske razine kalcidiola niže u djece i odraslih $\mathrm{s}$ atopijskim dermatitisom, a pojedina istraživanja dokazala su da u čak $70,5 \%$ pacijenata s vitiligom postoji nedostatak vitamina D. Niske razine vitamina D povezuju se i s progresijom malignog melanoma, no nepoznato je u kojem trenutku izloženosti UV zračenju vitamin $D$ prestaje djelovati protektivno i započinje biti rizični čimbenik za razvoj tumora kože. Unatoč brojnim provedenim istraživanjima, još uvijek nije poznata priroda odnosa vitamina $D$ i pojedinih kožnih bolesti, odnosno je li on uzročnoposljedičan ili slučajan, dok se u drugih dermatoza, poput psorijaze, dokazi o povezanosti s razinom vitamina $D$ primjenjuju u svakodnevnom radu s pacijentima - u dijagnostici $i$ liječenju.

Ključne riječi: koža; kožne bolesti; nedostatak vitamina D; vitamin D

Abstract. The relationship between vitamin $D$ and the skin starts with the synthesis of vitamin $D$ in the skin. New mechanisms on how the most researched vitamin affects the biggest organ in the human body are constantly investigated and observed. The aim is to review the current knowledge on vitamin $D$ and skin interaction, as well as the effect of vitamin $D$ levels on skin diseases. According to some studies, suboptimal vitamin D levels are found in as many as $30-90 \%$ of the population, with an estimated vitamin D insufficiency in about one billion people worldwide. In $25.6-68 \%$ of patients with psoriasis, there is a deficiency of vitamin $D$ and insufficiency of vitamin $D$ in as many as $97 \%$ of patients. Furthermore, a series of observational studies and meta-analyses have shown that the serum levels of calcidiol are lower in children and adults with atopic dermatitis, and some studies have shown that up to $70.5 \%$ of patients with vitiligo have vitamin D deficiency. Low levels of vitamin $D$ are associated with the progression of malignant melanoma, but it is unknown at which point UV exposure ceases to be protective through vitamin $D$ and begins to be a risk factor for the development of skin tumours. Despite many studies that have been conducted, the nature of the relationship between vitamin $D$ and certain skin diseases is still unknown, whether it is causal or accidental, while in others, such as psoriasis, evidence of the correlation with vitamin $\mathrm{D}$ levels is used in daily work with patients - in diagnosis and treatment.

Key words: skin; skin diseases; vitamin D; vitamin D deficiency 


\section{UVOD}

Vitamin D je liposolubilni steroidni hormon s pleiotropnim biološkim svojstvima koji može biti biljnog (ergokalciferol, vitamin D2) ili životinjskog podrijetla (kolekalciferol, vitamin D3). Ovisno o tome je li prehranom unesen u ljudski organizam ili sintetiziran i aktiviran nizom kemijskih reakcija koje se odvijaju u koži, jetri i bubrezima, razlikujemo egzogeni i endogeni vitamin D. Povezanost vitamina D i kože započinje sintezom vitamina D u koži, a neprestano se istražuju i uočavaju novi mehanizmi kojima najistraživaniji vitamin utječe na najveći organ ljudskoga tijela. Cilj je ovoga rada dati pregled dosadašnjih spoznaja o interakciji vitamina $D$ i kože te utjecaju razina vitamina $D$ na pojedine kožne bolesti.

VITAMIN D I KOŽA - FIZIOLOGIJA KAO UVOD U PATOFIZIOLOGIJU

\section{Fiziološke osobine vitamina D}

Budući da se vitamin D prirodno nalazi u vrlo malom broju prehrambenih namirnica, velik je značaj upravo endogeno sintetiziranog oblika vitamina D. Sunčevo ultraljubičasto B (engl. ultraviolet; UV) zračenje, elektromagnetno zračenje valne duljine 290 - $315 \mathrm{~nm}$, uzrokuje fotolitičku reakciju 7-dehidrokolesterola (engl. 7-dehydrocholesterol; 7-DHC) u bazalnom sloju epidermisa, čime nastaje previtamin D3 koji zatim izomerizacijom prelazi u vitamin D3. Oblik nastao ovim procesom nema biološke aktivnosti i nužna je njegova aktivacija reakcijama hidroksilacije. Prva se reakcija hidroksilacije odvija u jetri pomoću enzima vitamin D 25-hidroksilaze te time nastaje najvažniji cirkulirajući oblik vitamina D - 25-hidroksivitamin D3 (kalcidiol). Proces aktivacije vitamina D završava se u proksimalnom kanaliću bubrega pomoću enzima 1 $\alpha$-hidroksilaze (CYP27B1) te time nastaje aktivni oblik vitamina D - 1,25-dihidroksivitamin D3 (kalcitriol). CYP27B1 prisutan je i u keratinocitima u koži ${ }^{1}$. Metabolička inaktivacija obaju hidroksiliranih oblika posredovana je enzimom 24-hidroksilaze (CYP24A1).

Kalcitriol ima genetski i negenetski mehanizam djelovanja. Genetske učinke kalcitriol ostvaruje vezanjem na vitamin D receptor (VDR), koji nakon aktivacije ulazi $\mathrm{u}$ interakciju s retinoidnim $\mathrm{X}$ re- ceptorom. Novostvoreni heterodimerni kompleks zatim regulira ekspresiju ciljnih gena vezanjem na regulatorne sljedove DNA, koji se nazivaju elementima odgovora vitamina $D$, u centralnoj promotorskoj regiji.

Vitamin D potiče intestinalnu apsorpciju kalcija povećanjem sinteze kalbindina, proteina koji veže kalcij u enterocitima, čime omogućuje prijenos kalcija kroz četkastu prevlaku u citoplazmu enterocita. Prijenos kroz bazolateralnu membranu posredovan je procesom olakšane difuzije. Vitamin

Sukladno istraživanjima, peroralna i topikalna primjena kalcitriola te topikalna primjena takalcitola dovode do značajnog poboljšanja kožnih promjena u 70-80\% pacijenata i do njihove potpune regresije u $20-25 \%$ pacijenata sa psorijazom.

D izravno i neizravno, posredstvom kalcija, potiče apsorpciju fosfata u crijevima. Vitamin D snižava izlučivanje kalcija i fosfata bubregom povišenjem njihove reapsorpcije u području bubrežnih tubula, no ovaj je učinak slab i ne utječe značajno na izvanstanične koncentracije kalcija i fosfata. Kalcitriol potiče ekspresiju vaniloidnih receptora kanala prolaznog potencijala (engl. transient receptor potential vanilloid; TRPV) tip 5 i TRPV 6, kalcijskih kanala koji kontroliraju reapsorpciju kalcija na apikalnoj površini epitelnih stanica u bubrezima (TRPV 5) i crijevima (TRPV6) ${ }^{2}$. Manjim dijelom vitamin $D$ ostvaruje svoje učinke inhibicijom unutarstaničnih signalnih putova, poput hedgehog, $\beta$-kateninskog te signalnog puta jezgrinog čimbenika kapa B (engl. nuclear factor kappa light chain enhancer of activated B cells; NFKB) i fosfatidilinozitol-3-kinaze (engl. phosphatidylinositol-3-kinase; $\mathrm{PI} 3 \mathrm{~K})^{3,4}$.

Kalcitriol sintetiziran u keratinocitima regulira njihov rast, diferencijaciju, apoptozu i ostale biološke procese autokrinim i parakrinim učincima. U studijama in vitro dokazano je da vitamin D potiče proliferaciju keratinocita u niskim koncentracijama, a inhibiciju iste u visokim koncentracijama ${ }^{5}$. Kalcitriol inducira apoptozu keratinocita i ostalih stanica u epidermisu u farmakološkim dozama, dok u fiziološkim dozama inhibira učinak proapoptotičnih čimbenika, UV zračenja i čimbenika 
tumorske nekroze $\alpha$ (engl. tumor necrosis factor alpha; TNF- $\alpha)^{6}$. Brojne imunološke stanice, poput monocita, limfocita T i B te Langerhansovih stanica eksprimiraju VDR i CYP27B1 čime se ističe imunomodulacijski učinak vitamina D.

\section{Čimbenici koji utječu na razinu vitamina D u organizmu}

Niz ekstrinzičnih i intrinzičnih čimbenika utječe na razinu vitamina D u organizmu. Dnevne, sezonske i geografske varijacije $u$ intenzitetu te trajanje izloženosti UV-B zračenju najvažniji su ekstrinzični čimbenici ${ }^{7}$. Fototip kože određen Fitzpatrickovom ljestvicom (Tablica 1) ubraja se u intrinzičnu skupinu čimbenika. Pojedinci tamnije puti imaju višu koncentraciju melanina te im je potrebno duže izlaganje UV-B zračenju da bi stvorili jednake količine vitamina $D$ kao ljudi svjetlije puti $^{7}$. Stoga je razumljivo da su pojedinci tamnije puti skloniji nedostatku vitamina D (v. Nedovoljne razine vitamina $\mathrm{D})$.

\section{Nedovoljne razine vitamina D}

Hipovitaminoza D sve se češće uočava u razvijenim zemljama, a prevalencija se značajno razlikuje između pojedinih geografskih područja. Po nekim se istraživanjima suboptimalne razine vitamina D nalaze u čak 30-90 \% stanovništva, a procjenjuje se da manjak vitamina $D$ postoji u oko jedne milijarde ljudi na cijelome svijetu ${ }^{8}$. lako između pojedinih laboratorija mogu postojati manja odstupanja u referentnim vrijednostima potrebnima za određivanje nedovoljne količine vitamina D u organizmu, Američko društvo za endokrinologiju na temelju razine kalcidiola jasno je definiralo sljedeća stanja: nedostatak vitamina D (deficijencija) $\leq 20 \mathrm{ng} / \mathrm{mL}$, manjak vitamina D (in- suficijencija) $21-29 \mathrm{ng} / \mathrm{mL}$ i optimalnu razinu vitamina $\mathrm{D} \geq 30 \mathrm{ng} / \mathrm{mL}^{9}$.

\section{VITAMIN D I KOŽNE BOLESTI}

\section{Psorijaza}

Psorijaza je kronična upalna sustavna bolest, s prevalencijom oko $2-3 \%$, stoga je ta bolest i vrlo važan javnozdravstveni problem povezan sa smanjenjem kvalitete života pacijenata oboljelih od psorijaze. Najčešći klinički oblik psorijaze, vulgarna plak-psorijaza, očituje se simetričnim dobro ograničenim crvenim plakovima prekrivenim ljuskama ponajviše na ekstenzornim površinama ekstremiteta i u vlasištu. Danas je prva linija liječenja blage do umjereno teške plak-psorijaze topička primjena fiksne kombinacije kortikosteroida betametazona i analoga vitamina $\mathrm{D}^{10}$.

Procjenjuje se da u 25,6-68 \% pacijenata sa psorijazom postoji nedostatak vitamina $D$, a manjak vitamina D u čak $97 \%$ pacijenata $^{11,12}$. Sukladno istraživanjima, peroralna i topikalna primjena kalcitriola te topikalna primjena takalcitola dovode do značajnog poboljšanja kožnih promjena u 70$80 \%$ pacijenata i do njihove potpune regresije $u$ 20-25\% pacijenata sa psorijazom ${ }^{13}$. Analozi vitamina $D$ inhibiraju stvaranje citokina u T-limfocitima, dendritičkim stanicama i keratinocitima (Slika 1), a u kombinaciji s betametazonom sinergistički djeluju na smanjenje debljine epidermisa i infiltraciju kože CD4+ (engl. cluster of differentiation), CD8+, regulacijskim limfocitima $T$ te limfocitima $\mathrm{T}_{\mathrm{H}} 17 \mathrm{i} \mathrm{T}_{\mathrm{H}} 22 \mathrm{u}$ oboljelih od psorijaze ${ }^{14}$. Uočeno je smanjenje ekspresije niza proupalnih čimbenika u koži (TNF- $\alpha$, IL-12/23 p40, IL-17A, psorijazina, koebnerizina, kemokinskog liganda $s$ C-C motivom 20 i IFN- $p$ ) i u mononuklearnim

Tablica 1. Fitzpatrickova ljestvica (odgovor kože na prvo izlaganje podnevnom suncu tijekom ljeta, u trajanju od 30 minuta)

\begin{tabular}{|l|l|}
\hline \multicolumn{1}{|c|}{ Fototip } & \multicolumn{1}{c|}{ Značajke } \\
\hline I - izrazito svijetla put & Plava ili crvena boja kose, sunčane pjege, plave oči (uvijek izgore, nikada ne potamne) \\
\hline II - svijetla put & Plava ili smeđa boja kose, svijetla boja očiju (uvijek izgore na suncu, katkad potamne) \\
\hline III - malo tamnija put & Svjetlosmeđa boja kose, svijetla ili smeđa boja očiju (katkad izgore, uvijek potamne) \\
\hline IV - tamnija, maslinasta put & Tamnosmeđa ili crna boja kose, tamne oči (nikada ne izgore, uvijek potamne) \\
\hline V & Indijci, Arapi, Indijanci, Latinoamerikanci \\
\hline VI & Crna rasa \\
\hline
\end{tabular}


upalnim stanicama periferne krvi (TNF- $\alpha$, IL-6, IL-23A i IFN- $\gamma$ ) u pacijenata sa psorijazom liječenih kombinacijom kalcipotriola i betametazona ${ }^{14}$ ${ }^{15}$. Dakle, kalcipotriol pospješuje imunosupresivni učinak betametazona supresijom TNF- $\alpha$ - IL-23 IL-17 upalne osi. Vezanjem liganda za VDR dolazi do inhibicije ekspresije proupalnih citokina podrijetla T-limfocita, kao što su IL-2, IFN- - , IL-6 i IL- $8^{16}$. U koži pacijenata sa psorijazom kalcitriol potiče stvaranje protuupalnog citokina IL-10 i izražavanje njegovog receptora na staničnoj membrani keratinocita ${ }^{16}$. Aktivni oblik vitamina D i njegovi analozi inhibiraju diferencijaciju, sazrijevanje, aktivaciju i preživljavanje antigen-prezentirajućih stanica i dendritičkih stanica ${ }^{16}$. Pokazalo se da kalcitriol, 20(OH)D2 i 20,23(OH)2D inhibiraju transkripcijsku aktivnost NFkB, vrlo važnog pokretača upalnog odgovora ${ }^{17}$. Međutim, učinci analoga vitamina D na keratinocite u koži pacijenata sa psorijazom značajniji su od njihovih protuupalnih učinaka. Analozi vitamina D potiču diferencijaciju i apoptozu keratinocita te inhibiraju njihovu proliferaciju. Keratinociti eksprimiraju visoke razine CYP27B1, a kalcitriol, produkt navedenog enzima, potiče diferencijaciju keratinocita in vitro. $\mathrm{U}$ miševa u kojih ovaj enzim nedostaje, smanjena je količina involukrina, filagrina i lorikrina, markera diferencijacije keratinocita, molekula ključnih za stvaranje roževine i očuvanje integriteta epidermalne barijere, još jedne bitne točke u etiopatogenezi psorijaze ${ }^{1}$. U literaturi se spominje i učinak vitamina $D$ na ekspresiju proteina tijesnih veza $\mathrm{i}$ integrina u pacijenata sa psorijazom ${ }^{18}$.

Otkrivene su određene varijante u genima, koji kodiraju VDR i CYP24A1, čija prisutnost korelira s pojavnošću i težinom kliničke slike oboljelih, no samo u pojedinim etničkim skupinama ${ }^{19}$. U hrvatskoj populaciji to nije uočeno što ukazuje na možebitne individualne razlike u terapijskom odgovoru na vitamin $\mathrm{D}$ u pojedinim skupinama pacijenata ${ }^{20}$.

$U$ liječenju oboljelih od psorijaze često se primjenjuje UV-B zračenje uskog spektra (engl. narrowband UVB; NB-UVB). Na mišjem je modelu dokazano da NB-UVB fototerapija dovodi do bržeg oporavka kožne barijere i do povišenja razina filagrina i involukrina, a smatra se da je poticanje sinteze vitamina D fototerapijom zaslužno za

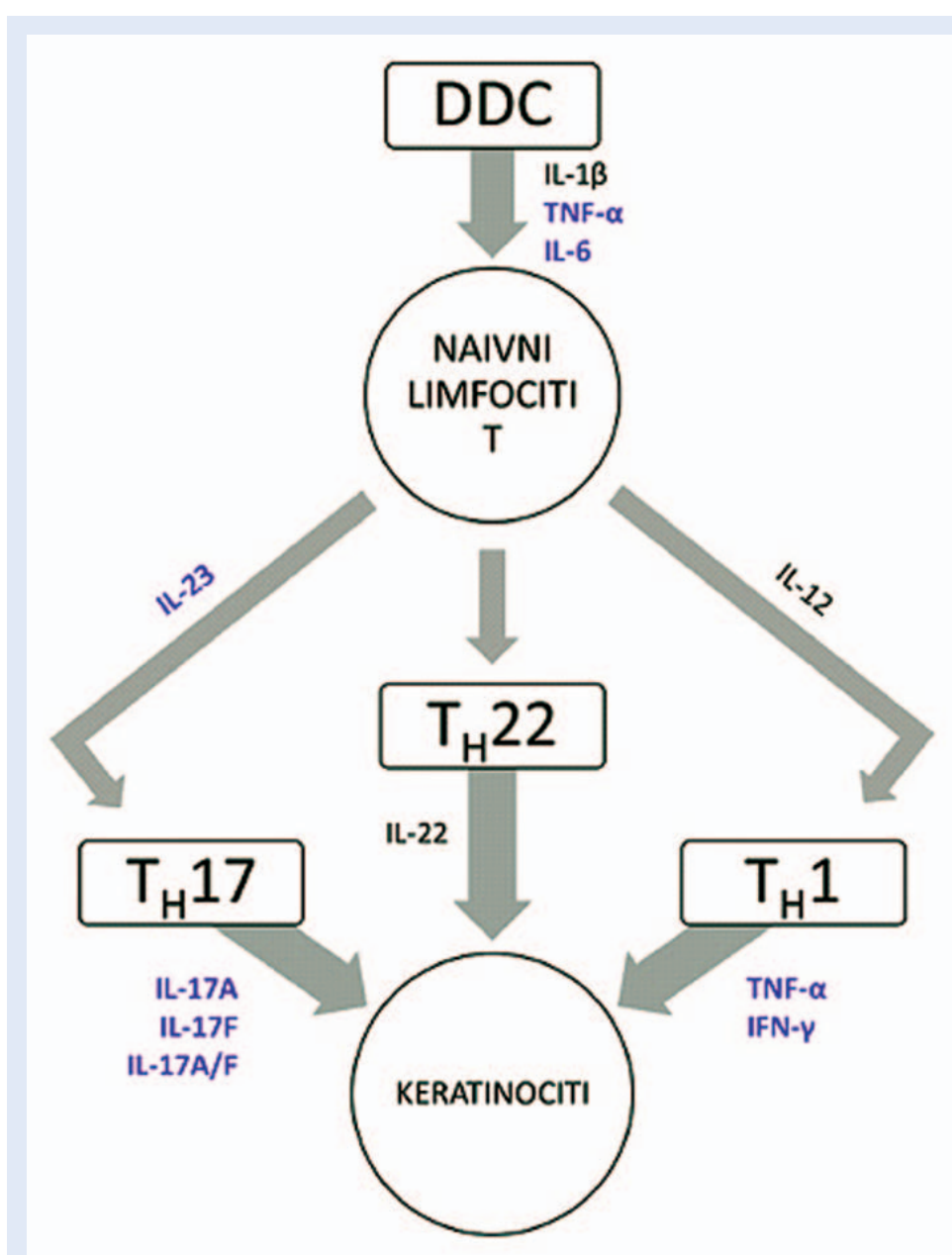

Slika 1. Utjecaj vitamina D na ključne etiopatogenetske mehanizme u podlozi psorijaze (točke na koje vitamin $D$ ima dokazani utjecaj istaknute su ljubičastom bojom; DDC = dermalne dendritičke stanice, engl. dermal dendritic cell; $\mathrm{T}_{H}=\mathrm{T}$ pomoćnićke stanice, engl. $T$ helper cells; IL = interleukin; TNF = čimbenik tumorske nekroze, engl. tumor necrosis factor; IFN = interferon)

ovaj njegov učinak u ubrzavanju oporavka epidermalne barijere ${ }^{21}$. Liječenje pacijenata sa psorijazom kombinacijom kalcipotriola i NB-UVB fototerapije pokazalo se učinkovitijim u poboljšanju kliničke slike od monoterapije navedenim metodama ${ }^{21}$.

\section{Atopijski dermatitis}

Atopijski dermatitis (AD) je kronična upalna kožna bolest koja se očituje svrbežom, ekcematoznim plakovima i oštećenjem epidermalne barijere. U razdoblju od 1960 . godine do danas uočen je trostruki porast $u$ prevalenciji AD-a22. Zbog svoje kronične, pruritične i bolne naravi, $A D$ može imati veći utjecaj na kvalitetu života nego 
astma, dijabetes, cistična fibroza i enureza. Epidemiološke studije ukazale su na povećanu prevalenciju $A D$-a u populacijama koje žive na višim geografskim širinama, gdje je manja izloženost UV-B zračenju i posljedično smanjeno stvaranje vitamina D. Nadalje, veća je vjerojatnost razvoja AD-a u pojedinaca s manjkom ili nedostatkom vitamina $D$, a serumske razine kalcidiola niže su u djece i odraslih s AD-om u odnosu na kontrolnu skupinu ${ }^{23-25}$. Djeca majki koje su unosile male količine hrane bogate vitaminom D tijekom trudnoće, imaju povišenu prevalenciju AD-a ${ }^{26}$. Povišena je prevalencija AD-a i u djece koja su rođena tijekom jesenskih i zimskih mjeseci u odnosu na djecu rođenu tijekom proljeća i ljeta, a uočena je i povezanost većeg unosa vitamina $D$ tijekom djetinjstva s povišenim rizikom za AD u dobi od 6 do 9 godina, i to neovisno o atopijskoj sklonosti u obitelji ${ }^{27,28}$.

Vitamin $D$ u pacijenata $S$ AD-om ima ponajprije protuupalni učinak. Vitamin D koči proliferaciju T-limfocita, prvenstveno pomoćničkih $\mathrm{T}$ (engl. T helper, $\mathrm{T}_{\mathrm{H}}$ ) - $\mathrm{T}_{\mathrm{H}} 1$ i $\mathrm{T}_{\mathrm{H}} 17$ limfocita, a time neizravno dovodi do smanjenja aktivacije makrofaga i dendritičkih stanica ${ }^{29}$. Suplementacija vitaminom D smanjuje lučenje proupalnih citokina poput IL-2, IL-4, IL-6, IL-17, TNF- $\alpha$ i interferon gama (IFN- $\gamma$ ) te potiče protuupalni učinak regulacijskih T-limfocita posredovan s IL-10 u pacijenata S AD-om i nedostatkom vitamina $D^{29}$. Povišena razina imunoglobulina $E$ ( $\operatorname{IgE})$, kao odgovor na okolišne i nutritivne alergene, nazočna je $u$ pacijenata $s$ $A D$-om, a upravo vitamin $D$ koči stvaranje IgE $u$ B-limfocitima i time smanjuje aktivaciju mastocita u uvjetima in vivo i in vitro ${ }^{30}$. Osim učinka na sastavnice stečenog imunološkog sustava, poticanjem ispoljavanja filagrina i involukrina u keratinocitima, vitamin D sudjeluje i u obnovi poremećaja epidermalne barijere, vrlo bitne sastavnice prirođenog imunološkog odgovora.

Topikalna primjena i peroralno uzimanje vitamina D potiče ekspresiju LL-37 u promijenjenoj i nepromijenjenoj koži pacijenata $S$ AD-om i dovodi do kliničkog poboljšanja, a antimikrobni učinak vitamina $D$ posredovan je i povećanom ekspresijom antimikrobnog peptida katelicidina, tzv. endogenog antibiotika, u keratinocitima. Pacijenti s AD-om skloni su kolonizaciji i infekciji kože zlat- nim stafilokokom, a uz snižene serumske razine kalcidiola ta se sklonost dodatno povećava. U posljednje vrijeme intenzivno se istražuju različite genske varijante u genima koji kodiraju VDR, CYP24A1 i CYP27B1, a pojedine od njih povezuju se $s$ povišenim rizikom za razvoj teškog kliničkog oblika AD-a, što se objašnjava smanjenim protuupalnim učinkom vitamina $D$ u pacijenata s određenom genetskom predispozicijom ${ }^{31}$.

Unatoč tome što postoji velik broj podataka koji svjedoče o učinkovitosti vitamina $D$ u liječenju AD-a, zbog geografskih, sezonskih i prehrambenih razlika koje mogu utjecati na razine vitamina $D$ i time interferirati s dobivenim rezultatima te zbog nedosljednosti rezultata, potrebno je $\mathrm{s}$ oprezom interpretirati sve dobivene rezultate.

\section{Vitiligo}

Vitiligo je stečeni poremećaj pigmentacije koji se očituje različito velikim područjima depigmentacije kože, kose i/ili sluznica. lako točan uzrok vitiliga nije poznat, vjerojatno se radi o autoimunosnom poremećaju uz koji se vrlo često, u čak trećine pacijenata s vitiligom, pojavljuju i ostale autoimune bolesti. Nedostatak vitamina D smatra se jednim od okolišnih 'okidača' koji mogu potaknuti autoimunosna zbivanja i manifestaciju autoimunosnih bolesti. Serumske koncentracije kalcidiola značajno su niže $u$ pacijenata $s$ vitiligom $u$ odnosu na zdrave pojedince. Pojedina istraživanja dokazala su da u čak 70,5\% pacijenata s vitiligom postoji nedostatak vitamina $\mathrm{D}^{32}$. Polimorfizmi VDR gena povezuju se s povišenim rizikom za razvoj autoimunih bolesti, poput Hashimotovog tireoiditisa, upalnih bolesti crijeva, Gravesove bolesti, reumatoidnog artritisa, sistemskog eritematoznog lupusa, primarne bilijarne ciroze, autoimunog hepatitisa, Addisonove bolesti, celijakije, šećerne bolesti tipa 1, multiple skleroze i vitiliga. Manjkavost ovih istraživanja jest uključenost pretežno in vitro i animalnih studija, a dostupni su rezultati istraživanja na ljudima neusuglašeni. U liječenju vitiliga, osim prve linije liječenja lokalnim kortikosteroidima, može se primjenjivati kombinacija PUVA (psoralen-UVA) i analoga vitamina D kalcipotriola. Analozi vitamina D u monoterapiji nisu učinkoviti koliko i lokalni kortikosteroidi, ali njihova primjena u kombinaciji s kortikosteroidima po- 
većava učinkovitost liječenja. Vitamin D kontrolira aktivaciju, proliferaciju i migraciju melanocita, inhibira apoptozu melanocita te potiče melanogenezu i povišenje sadržaja tirozinaze u staničnoj kulturi humanih melanocita. Modulacijom aktivacije T-limfocita, vitamin D omogućuje smanjenje autoimunosnog oštećenja melanocita. Dokazano je da pacijenti s vitiligom, koji imaju snižene serumske razine kalcidiola, imaju povišen rizik za razvoj sekundarnih oblika autoimunosti, što bi se moglo upotrijebiti u probiru na prisustvo autoimunosnih komorbiditeta u pacijenata s vitiligom. lako je topikalno liječenje analozima vitamina D pokazalo značajno kliničko poboljšanje vitiliga, uloga peroralne primjene vitamina $D$ još je nedovoljno istražena. Preliminarna istraživanja ukazuju da peroralno uzimanje kalcitriola u razdoblju od šest mjeseci dovodi do 25 - 75 \% repigmentacije u $88 \%$ ispitanika, bez značajnih promjena u metaboličkim parametrima ${ }^{33}$. Stoga, iako liječenje kalcitriolom može biti učinkovito i sigurno u pacijenata s vitiligom, potrebna su daljnja istraživanja u ovome području kako bi se doneseni zaključci mogli primijeniti u kliničkom radu.

\section{Maligni tumori kože}

Maligni tumori kože važan su javnozdravstveni problem jer postoji tendencija porasta njihove incidencije u svijetu, posebice u osoba bijele rase. Prema podrijetlu transformiranih stanica, maligni tumori kože dijele se na bazocelularni karcinom (engl. basal-cell carcinoma; BCC), planocelularni karcinom (engl. squamous cell carcinoma; SCC) i maligni melanom (MM). BCC i PCC imaju bolju prognozu i češće se javljaju od MM-a, a predilekcijska mjesta za njihov nastanak su područja kože izložena suncu. MM se može pojaviti u bilo kojem tkivu koje sadrži melanocite i vrlo je sklon metastaziranju te ima najvišu stopu mortaliteta među svim tumorima kože. Postoje tri skupine rizičnih čimbenika za razvoj tumora kože: okolišni, fenotipski i genetski. Najvažniji okolišni rizični čimbenik za razvoj tumora kože jest izloženost kože UV zračenju. Oksidacijski stres i oštećenje DNA temelj su karcinogenog djelovanja UV zračenja, a čak je oko 65 \% MM-a i $90 \%$ svih tumora kože povezano $s$ izlaganjem UV zračenju ${ }^{16}$. Fenotipski rizični čimbenik za razvoj tumora kože je prisustvo foto- tipa I i fototipa II (Tablica 1). Genetski rizični čimbenici vrlo su bitni jer se $10 \%$ MM-a javlja u obiteljima s najmanje dva slučaja MM-a u bližih srodnika, a genetički mehanizmi u podlozi aktivno se istražuju ${ }^{34}$. Postavlja se pitanje je li vitamin D protektivni ili rizični čimbenik, s obzirom na to da je za više razine vitamina $D$ potrebno duže izlaganje UV zračenju. Epidemiološke studije pokazale su recipročan odnos serumskih koncentracija kalcidiola i incidencije tumora, odnosno mortaliteta u pacijenata $s$ različitim tipovima ne-

Unatoč tome što postoji veliki broj podataka koji svjedoče o učinkovitosti vitamina $D$ u liječenju $A D-a$, zbog geografskih, sezonskih i prehrambenih razlika koje mogu utjecati na razine vitamina $D$ i time interferirati $s$ dobivenim rezultatima te zbog nedosljednosti rezultata, potrebno je s oprezom interpretirati sve dobivene rezultate.

oplazmi, kao što su karcinom debelog crijeva, karcinom dojke i karcinom prostate ${ }^{7}$. Niske razine vitamina $D$ povezuju se s progresijom MM-a, no nepoznato je u kojem trenutku izloženost UV zračenju prestaje djelovati protektivno posredstvom vitamina D i započinje biti rizični čimbenik za razvoj tumora kože. Prema navodima u literaturi, vitamin $D$ pokazuje dozno-ovisni inhibicijski učinak na rast stanica MM-a jer djeluje antiproliferativno, kako na zdrave tako i na maligno promijenjene stanice koje eksprimiraju VDR. Usto, vitamin D utječe na proces fosforilacije tumorsupresorskih gena, inhibira ekspresiju ciklina D1E i ciklina A te ciklin-ovisnih kinaza (engl. cyclin dependent kinase; CDK) CDK2, CDK4 i CDK6 ${ }^{35}$. Nadalje, vitamin $D$ regulira ekspresiju inhibitora ciklin-ovisnih kinaza p21 i p27, potiče ekspresiju GADD45, p53 i ostalih tumorsupresorskih gena te smanjuje staničnu proliferaciju posredstvom Forkhead box $O$ transkripcijskih čimbenika te Myc, Fos i Jun onkogena ${ }^{36}$. Vitamin D istovremeno potiče diferencijaciju i sazrijevanje stanica regulacijom staničnih signalnih puteva, kao što su hedgehog (posebice u BCC), $\beta$-kateninski, NFKB i $\mathrm{PI3K}$ signalni put ${ }^{37}$. Osim antiproliferacijskog učinka, vitamin D pokazuje i vrlo važan proapoptotični učinak u tumorskih stanica. Ovaj učinak može 
biti posredovan različitim mehanizmima: (1) indukcijom ekspresije p73 proteina, (2) oštećenjem funkcije mitohondrija, (3) oslobađanjem citokroma C, (4) stvaranjem reaktivnih kisikovih spojeva, (5) inhibicijom antiapoptotičnih čimbenika Bcl-2 (engl. B cell lymphoma) i Bcl-XL, (6) indukcijom niza proapoptotičkih čimbenika, poput BAX (engl. Bcl-2-associated $X$ protein), GOS2 (engl. GO/G1 switch protein 2), DAP-3 (engl. death-associated protein 3), FADD (engl. Fas-associated death domain) te kaspaza 3, 4, 6 i 8, (7) poticanjem oslobađanja i unosa kalcija u tumorske stanice i aktivacijom kaspaze 12 ovisne o kalciju, (8) inhibicijom telomerazne reverzne transkriptaze ${ }^{38}$. Usto, vitamin D potiče proces autofagije inhibicijom mTOR (engl. mammalian target of rapamycin) gena i stimulacijom beklina-1, a tim procesom tumorske stanice mogu postati osjetljivije na onkološko liječenje ${ }^{39}$. Nekoliko istraživanja govori u prilog tome da vitamin D smanjuje vaskularizaciju tumora inhibicijom ekspresije vaskularnog endotelnog čimbenika rasta (engl. vascular endothelial growth factor; VEGF) u stanjima hipoksije ili inhibicijom ekspresije drugih proangiogenih čimbenika, poput ciklooksigenaze-2 ili IL- $8^{40}$. Na mišjem modelu bez VDR gena dolazi do pojačane ekspresije proangiogenih čimbenika, poput hipoksijom induciranog čimbenika 1, VEGF, angiopoetina i čimbenika rasta podrijetlom iz trombocita ${ }^{40}$. Vitamin D smanjuje invaziju i migraciju tumorskih stanica smanjenjem ekspresije laminina i njegovih receptora, inhibicijom matriksnih metaloproteinaza i katepsina te povećanjem ekspresije E-kadherina ${ }^{16}$.

Serumske koncentracije kalcidiola te ekspresija VDR-a i CYP2B1 potencijalni su prognostički čimbenici u pacijenata s MM-om. Niske serumske koncentracije kalcidiola u pacijenata s MM-om povezuju se s višim stupnjem na Breslow ljestvici i s kraćim preživljavanjem ${ }^{41}$. Smanjena ekspresija VDR-a povezuje se s uznapredovalim stadijem $M M-a, s$ vertikalnim načinom rasta, s najvišim stupnjem na Breslow i Clark ljestvici, s ulceriranom površinom, sa smanjenom limfocitnom infiltracijom i s nodularnim tipom MM-a ${ }^{41}$. Iznimka su stanice slabije diferenciranih amelanotičnih MM-a s visokim stupnjem proliferacije koje iz nepoznatog razloga bolje odgovaraju na primjenu vitamina D od melanomskih stanica višeg stupnja diferencijacije. Identificirano je više od 1000 polimorfnih područja u VDR genu, a pojedina od njih povezana su s povišenim rizikom za razvoj MM-a te $s$ agresivnijim tipom MM-a i lošijom prognozom ${ }^{16}$. Nadalje, u melanomskih stanica pacijenata s MM-om postoji značajno smanjenje ekspresije CYP2B1 u odnosu na kožu zdravih pojedinaca, a razina ekspresije CYP2B1 korelira $s$ agresivnošću i uznapredovalošću MM-a te s kraćim preživljavanjem tih pacijenata ${ }^{42}$. Usto, povećana ekspresija CYP24A1 u pacijenata s MM-om povezuje se $s$ ranijim stadijima tumora i s nižim Breslow i Clark stupnjem, a smanjena ekspresija s nodularnim tipom, visokim stupnjem proliferacije, prisutnošću ulceracije i nekroze te s kraćim preživljavanjem u toj skupini pacijenata ${ }^{43}$. Prema tome, postoje brojni dokazi da vitamin D pozitivno utječe na maligne tumore kože, posebice na MM, stoga bi daljnja istraživanja trebalo usmjeriti u razvoj novih metoda liječenja.

\section{ZAKLJUČAK}

Unatoč brojnim provedenim istraživanjima, još uvijek nije poznata točna priroda odnosa vitamina $D$ i pojedinih kožnih bolesti, odnosno je li on uzročno-posljedičan ili slučajan, dok se u drugih, poput psorijaze, dokazi o povezanosti s razinom vitamina $D$ primjenjuju u svakodnevnom radu $\mathrm{s}$ pacijentima - u dijagnostici i liječenju.

Izjava o sukobu interesa: Autori izjavljuju kako ne postoji sukob interesa.

\section{LITERATURA}

1. Bikle DD, Chang S, Crumrine D, Elalieh $H$, Man $M Q$, Dardenne $O$ et al. Mice lacking 25OHD 1alpha-hydroxylase demonstrate decreased epidermal differentiation and barrier function. J Steroid Biochem Mol Biol 2004;90:347-53.

2. Van Goor MKC, Hoenderop JGJ, van der Wijst J. TRP channels in calcium homeostasis: from hormonal control to structure-function relationship of TRPV5 and TRPV6. Biochim Biophys Acta 2017;1864:883-93.

3. Axanova LS, Chen YQ, McCoy T, Sui G, Cramer SD. 1,25-dihydroxyvitamin D(3) and PI3K/AKT inhibitors synergistically inhibit growth and induce senescence in prostate cancer cells. Prostate 2010;70:1658-71.

4. Uhmann A, Niemann H, Lammering B, Henkel C, Hess I, Nitzki $F$ et al. Antitumoral effects of calcitriol in basal cell carcinomas involve inhibition of hedgehog signaling and induction of vitamin D receptor signaling and differentiation. Mol Cancer Ther 2011;10:2179-88. 
5. Umar M, Sastry KS, Al Ali F, Al-Khulaifi M, Wang E, Chouchane Al. Vitamin D and the Pathophysiology of Inflammatory Skin Diseases. Skin Pharmacol Physiol 2018;31:74-86.

6. Manggau M, Kim DS, Ruwisch L, Vogler R, Korting HC, Schafer-Korting $\mathrm{M}$ et al. 1 $\alpha, 25$-Dihydroxyvitamin D3 protects human keratinocytes from apoptosis by the formation of sphingosine-1-phosphate. J Invest Dermatol 2001;117:1241-9.

7. Tsiaras WG, Weinstock MA. Factors influencing vitamin D status. Acta Derm Venereol 2011;91:115-24.

8. Arabi A, El Rassi R, El-Hajj Fuleihan G. Hypovitaminosis D in developing countries - prevalence, risk factors and outcomes. Nat Rev Endocrinol 2010;6:550-61.

9. Holick MF, Binkley NC, Bischoff-Ferrari HA, Gordon CM, Hanley DA, Heaney RP et al. Evaluation, treatment, and prevention of vitamin $D$ deficiency: an Endocrine Society clinical practice guideline. J Clin Endocrinol Metab 2011;96:1911-30.

10. Morimoto S, Kumahara Y. A patient with psoriasis cured by $1 \alpha$-hydroxyvitamin D3. Med J Osaka Univ 1985;35: 3-4.

11. Wadhwa B, Relhan V, Goel K, Kochhar AM, Garg VK. Vitamin $D$ and skin diseases: A review. Indian J Dermatol Venereol Leprol 2015;81:344-55.

12. Ricceri F, Pescitelli L, Tripo L, Prignano F. Deficiency of serum concentration of 25-hydroxyvitamin $D$ correlates with severity of disease in chronic plaque psoriasis. J Am Acad Dermatol 2013;68:511-2.

13. Nagpal S, Lu J, Boehm MF. Vitamin D analogs: mechanism of action and therapeutic applications. Curr Med Chem 2001;8:1661-79.

14. Kubin $M E$, Kokkonen $N$, Palatsi R, Hägg $P M$, Väyrynen JP, Glumoff $V$ et al. Clinical Efficiency of Topical Calcipotriol/ Betamethasone Treatment in Psoriasis Relies on Suppression of the Inflammatory TNF $\alpha$ - IL-23 - IL-17 Axis. Acta Derm Venereol 2017;97:449-55.

15. Hegyi Z, Zwicker S, Bureik D, Peric M, Koglin S, BatyckaBaran A et al. Vitamin D analog calcipotriol suppresses the Th17 cytokine-induced proinflammatory S100 "alarmins" psoriasin (S100A7) and koebnerisin (S100A15) in psoriasis. J Invest Dermatol 2012;132:1416-24.

16. Piotrowska A, Wierzbicka J, Żmijewski MA. Vitamin D in the skin physiology and pathology. Acta Biochim Pol 2016;63:17-29.

17. Janjetovic Z, Tuckey RC, Nguyen MN, Thorpe EM, Slominski AT. 20,23-dihydroxyvitamin D3, novel P450scc product, stimulates differentiation and inhibits proliferation and NF-kappaB activity in human keratinocytes. $J$ Cell Physiol 2010;223:36-48.

18. Visconti B, Paolino G, Carotti S, Pendolino AL, Morini S, Richetta AG et al. Immunohistochemical expression of VDR is associated with reduced integrity of tight junction complex in psoriatic skin. J Eur Acad Dermatol Venereol 2015;29:2038-42.

19. Liu JL, Zhang SQ, Zeng HM. Apal, Bsml, Fokl and Taql polymorphisms in the vitamin $D$ receptor (VDR) gene and the risk of psoriasis: a meta-analysis. J Eur Acad Dermatol Venereol 2013;27:739-46.

20. Rucevic I, Stefanic M, Tokic S, Vuksic M, Glavas-Obrovac L, Barisic-Drusko V. Lack of association of vitamin D receptor gene 3 '-haplotypes with psoriasis in Croatian patients. J Dermatol 2012:39:58-62.
21. Takahashi H, Tsuji H, Ishida-Yamamoto A, lizuka H. Comparison of clinical effects of psoriasis treatment regimens among calcipotriol alone, narrowband ultraviolet B phototherapy alone, combination of calcipotriol and narrowband ultraviolet B phototherapy once a week, and combination of calcipotriol and narrowband ultraviolet B phototherapy more than twice a week. J Dermatol 2013;40:424-7.

22. Mesquita KDC, Igreja ACDSM, Costa IMC. Atopic dermatitis and vitamin D: facts and controversies. An Bras Dermatol 2013;88:945-53.

23. Cheng HM, Kim S, Park GH, Chang SE, Bang S, Won CH et al. Low vitamin $D$ levels are associated with atopic dermatitis, but not allergic rhinitis, asthma, or IgE sensitization, in the adult Korean population. J Allergy Clin Immunol 2014;133:1048-55.

24. El Taieb MA, Fayed HM, Aly SS, Ibrahim AK. Assessment of serum 25-hydroxyvitamin $D$ levels in children with atopic dermatitis: correlation with SCORAD index. Dermatitis 2013;24:296-301.

25. Kim MJ, Kim SN, Lee YW, Choe YB, Ahn KJ. Vitamin D status and efficacy of vitamin D supplementation in atopic dermatitis: a systematic review and meta-analysis. Nutrients 2016;8:789.

26. Miyake Y, Tanaka K, Okubo H, Sasaki S, Arakawa M. Maternal consumption of dairy products, calcium, and vitamin D during pregnancy and infantile allergic disorders. Ann Allergy Asthma Immunol 2014;113:82-7.

27. Kuzume K, Kusu M. Before-birth climatologic data may play a role in the development of allergies in infants. Pediatr Allergy Immunol 2007;18:281-7.

28. Bäck O, Blomquist HK, Hernell O, Stenberg B. Does vitamin $D$ intake during infancy promote the development of atopic allergy? Acta Derm Venereol 2009;89:28-32.

29. Di Filippo P, Scaparrotta A, Rapino D, Cingolani A, Attanasi $\mathrm{M}$, Petrosino $\mathrm{Ml}$ et al. Vitamin D supplementation modulates the immune system and improves atopic dermatitis in children. Int Arch Allergy Immunol 2015;166:91-6.

30. Yip KH, Kolesnikoff N, Yu C, Hauschild N, Taing H, Biggs L et al. Mechanisms of vitamin $\mathrm{D}(3)$ metabolite repression of IgE-dependent mast cell activation. J Allergy Clin Immunol 2014;133:1356-64.

31. Heine G, Hoefer N, Franke A, Nöthling U, Schumann RR, Hamann $L$ et al. Association of vitamin $D$ receptor gene polymorphisms with severe atopic dermatitis in adults. Br J Dermatol 2013;168:855-8.

32. Aksu Cerman A, Sarikaya Solak S, Kivanc Altunay I. Vitamin $\mathrm{D}$ deficiency in alopecia areata. $\mathrm{Br} J$ Dermatol 2014;170:1299-304.

33. Finamor DC, Sinigaglia-Coimbra R, Neves LC, Gutierrez $M$, Silva JJ, Torres LD et al. A pilot study assessing the effect of prolonged administration of high daily doses of vitamin $\mathrm{D}$ on the clinical course of vitiligo and psoriasis. Dermatoendocrinol 2013;5:222-34.

34. Gandini S, Sera F, Cattaruzza MS, Pasquini P, Zanetti R, Masini $C$ et al. Meta-analysis of risk factors for cutaneous melanoma: III. Family history, actinic damage and phenotypic factors. Eur J Cancer 2005;41:2040-59.

35. Bouillon R, Eelen G, Verlinden L, Mathieu C, Carmeliet G, Verstuyf A. Vitamin D and cancer. J Steroid Biochem Mol Biol 2006;102:156-62.

36. An BS, Tavera-Mendoza LE, Dimitrov V, Wang X, Calderon MR, Wang $\mathrm{HJ}$ et al. Stimulation of Sirt1-regulated 
FoxO protein function by the ligand-bound vitamin $D$ receptor. Mol Cell Biol 2010;30:4890-900.

37. Moukayed M, Grant WB. Molecular link between vitamin D and cancer prevention. Nutritients 2013;5:3993-4021.

38. Feldman D, Krishnan AV, Swami S, Giovannucci E, Feldman BJ. The role of vitamin $D$ in reducing cancer risk and progression. Nat Rev Cancer 2014:14:342-57.

39. Lisse TS, Liu T, Irmler M, Beckers J, Chen H, Adams JS et al. Gene targeting by the vitamin $D$ response element binding protein reveals a role for vitamin $D$ in osteoblast mTOR signaling. FASEB J 2011;25:937-47.

40. Ben-Shoshan M, Amir S, Dang DT, Dang LH, Weisman Y, Mabjeesh NJ. 1,25-dihydroxyvitamin D3 (Calcitriol) inhibits hypoxia-inducible factor-1/vascular endothelial growth factor pathway in human cancer cells. Mol Cancer Ther 2007;6:1433-9.

41. Brozyna AA, Jozwicki W, Slominski AT. Decreased VDR expression in cutaneous melanomas as marker of tumor progression: new data and analyses. Anticancer Res 2014;34:2735-43.

42. Brozyna AA, Jozwicki W, Janjetovic Z, Slominski AT. Expression of the vitamin $D$-activating enzyme 1alpha-hydroxylase (CYP27B1) decreases during melanoma progression. Hum Pathol 2013;44:374-87.

43. Brozyna AA, Jochymski C, Janjetovic $Z$, Jóźwicki $W$, Tuckey RC, Slominski AT. CYP24A1 expression inversely correlates with melanoma progression: clinic-pathological studies. Int J Mol Sci 2014;15:19000-19017. 